$2020,21(1)$, Pp. 97 - 105, DOI: 10.18038/estubtda. 688451

\title{
DETERMINATION OF THE EFFECT OF ENERGY CONSUMPTION ON ECONOMIC GROWTH IN CENTRAL ASIAN TURKISH REPUBLICS
}

\author{
Fatih ÇEMREK ${ }^{1, *}$ \\ ${ }^{1}$ Department of Statistics, Faculty of Science and Letters, Eskişehir Osmangazi University, Eskişehir, Turkey
}

\begin{abstract}
Energy plays an important role in the economic growth, social development and individuals' prosperity and comfort of countries. The effect of energy consumption on economic growth depends on the economic structure of the country.

In this study, electricity consumption per capita (kwh) and Gross Domestic Product per capita(\$) for the period covering 19912014 for six countries in Central Asia (Azerbaijan, Kazakhstan, Kyrgyzstan, Tajikistan, Turkmenistan and Uzbekistan) panel data analysis was used to investigate the relationship between the series. According to the results, the existence of the cointegration relationship between the variables discussed in the examined countries was determined.
\end{abstract}

Keywords: Energy, Economic Growth, Causality, Central Asian Turkish Republics, Panel Data Analysis

\section{INTRODUCTION}

Energy is among the main production inputs used to increase the economic development of countries and the living levels of societies. The effect of energy consumption on economic growth varies between countries. After the Turkish Republics, which are among the transition economies, gained their independence, they started various reform and privatization studies during the transition to the market economy. Due to the natural resource reserves and geostrategic features of these countries, they have gained an important place among emerging economies.

When the development experiences of developed countries are researched, it is observed that there is a transition towards increasingly more intensive energy types in energy consumption. The main reasons for this are the increase in the amount of use of production factors in the process of economic growth, as well as the use of them more effectively and efficiently.

There is a two-way relationship between economic growth and energy consumption. Energy consumption increases as a result of economic growth, and energy consumption accelerates growth. Energy use makes investments more efficient, accelerates technical advances and increases labor productivity.

The oil crises that occurred in the 1970s and subsequent oil price shocks led to increased research on the relationship between energy and economic growth.

There are four major hypotheses in the literature to explain the relationship between energy consumption and economic growth [1]. According to the Neutrality Hypothesis, there is no relationship between these variables. In terms of the Protectionist Hypothesis, there is a unidirectional relationship from economic growth to energy consumption, and it is stated that protective policies may not have an impact on economic growth. It is stated in the Growth Hypothesis that there is a unidirectional relationship from energy consumption to economic growth, and economic growth will increase as energy consumption increases.

*Corresponding Author: fcemrek@ogu.edu.tr 0222393750 -2108

Received: 16.02.2020 Published: 31.03.2020 
On the other hand, policies to reduce energy consumption affect economic growth negatively. Finally, in terms of Feedback Hypothesis, there is a two-way relationship between these two variables, and changes in economic growth or energy consumption affect each other mutually.

The first study to investigate the relationship between energy consumption and economic growth is accepted as the paper by [2]. In the U.S., they found that there was a unidirectional causality from GNP to energy consumption in the study using data from the 1947-1974 period, and this result was later supported by various researchers.

A cointegration and vector error correction model was used for the period between 1955 and 1990 in for India, Pakistan, Malaysia, Singapore, Indonesia and the Philippines. At the end of the analysis, they stated that while there is a certain causal relationship between energy consumption and growth for Malaysia, in India causality from energy consumption to economic growth, in Indonesia causality from economic growth to energy consumption, and in Pakistan there is two-way causality between both variables [3].

Using data from the period 1971-2002, it was investigated the relationship between panel cointegration and causality tests, and energy consumption and economic growth in 16 Asian countries. While there is no relationship between energy consumption and growth in the short term, causality was determined from energy consumption to economic growth in the long term [4].

It was investigated the causal relationship between energy consumption and economic growth in China in the period of 1953-2006 by the ADF unit root test, cointegration and Hsiao's Granger causality tests. As a result of the analysis, it was revealed that economic growth is the cause of energy consumption and energy consumption is the cause of economic growth [5].

It was investigated the short and long term causality relationships between energy consumption and real GDP in 25 OECD countries for the 1981-2007 period. They concluded that the long-term relationship between energy consumption and real GDP is more effective than the short term [6].

The relationship between energy consumption and economic growth analyzed by panel data method in 80 developing countries in the period of 1990-2009, and stated that there was a long term positive relationship between the variables [7].

The causality relationship between energy consumption and economic growth was handled with the bootstrap-Granger causality approach. To the study, there was bi-directional causality between energy consumption and GDP in Canada, Japan and the USA, and a unidirectional causality from GDP to energy consumption in France and Germany. However, no causality was determined for Italy and the UK [8].

A study was conducted to investigate the relationship between sectoral energy consumption and economic growth in Turkey for the period of 1970-2012 by Toda-Yamamoto causality test. As a result of the study, it was observed that there was a two-way causality relationship between energy consumption and economic growth in the industry and transportation sectors. On the other hand, in the agriculture and housing sector, no causal relationship was found between energy consumption and economic growth [9].

The relationship between tourism revenues, energy consumption and economic growth analyzed in the transition economies for the years between 1995 and 2014. According to analyzes, the tourism-based growth hypothesis was valid in Armenia, Kazakhstan, Russia, Albania and Hungary, and the energybased growth hypothesis was valid in Azerbaijan, Kyrgyzstan and Poland [10].

The relationship between energy consumption and economic growth was examined the in Central Asian countries. In the study, panel data analysis with annual data for the period of 1991-2016 (26 years) was 
applied for the countries studied. The study concluded that there was a bidirectional causality relationship between energy consumption and economic growth in Central Asian countries [11].

Other studies using panel data analysis between Central Asian countries and other transition economy countries can also be examined [12-16].

The aim of this study is to determine whether causality exists between energy consumption and economic growth variables for Azerbaijan, Kazakhstan, Kyrgyzstan, Uzbekistan, Tajikistan, and Turkmenistan. In the study, panel data analysis was used as econometric analysis.

\section{ENERGY POTENTIAL PRODUCTION AND CONSUMPTION OF CENTRAL ASIAN TURKISH REPUBLICS}

Energy reserves, energy consumption and development levels are different from each other in Azerbaijan, Kazakhstan, Kyrgyzstan, Uzbekistan, Tajikistan and Turkmenistan, which are discussed in the study. There are significant oil, natural gas and coal reserves in Azerbaijan, Kazakhstan, Turkmenistan and Uzbekistan. Kyrgyzstan and Tajikistan have a large capacity in terms of hydroelectric resources.

In 2018, Azerbaijan has a reserve of 1.0 thousand million tons; Kazakhstan, 3.9 thousand million tons; Turkmenistan, 0.1 thousand million tons; and Uzbekistan, 0.6 thousand million tons. From these reserves, 39.2 million tons of oil in Azerbaijan, 91.2 million tons of oil in Kazakhstan, 10.6 million tons of oil in Turkmenistan, and 2.9 million tons of oil in Uzbekistan were produced in the same year. As of 2018, Azerbaijan made 18.8 billion $\mathrm{m}^{3}$ natural gas production from the natural gas reserves of 2.1 trillion $\mathrm{m} 3$, Kazakhstan 24.4 billion $\mathrm{m}^{3}$ natural gas production from 1.0 trillion m3natural gas reserves, Turkmenistan 61.5 billion $\mathrm{m}^{3}$ natural gas production from the reserve of 19.5 trillion $\mathrm{m} 3$ natural gas, and Uzbekistan 56.6 billion $\mathrm{m}^{3}$ natural gas production from the natural gas reserve of 1.2 trillion $\mathrm{m}^{3}$. There are 25.6 million tons of coal reserves in Kazakhstan and 1.4 million tons of coal in Uzbekistan. In terms of coal production, Kazakhstan had 50.6 million tons of equivalent oil and 3.0 million tons of equivalent oil in Uzbekistan [17].

According to the energy consumption sources of Kyrgyzstan in 2017; oil consumption was 36000 barrels per day, natural gas 14 billion cubic feet, and coal consumption 0.8 million tons. Energy consumption in Tajikistan, according to sources, oil consumption was 13000 barrels per day, natural gas 7.5 billion cubic feet, and coal consumption 0.2 million tons.

Table 1 and 2 show the types and quantities of energy consumed by the Turkic Republics for 2017 and 2018.

Table 1. Primary Energy Consumption of Turkish Republics in 2017 (Million TEO)

\begin{tabular}{lccccccc}
\hline & Oil & Natural Gas & Coal & Nuclear & Hydraulic & Renewable & Total \\
\hline Azerbaijan & 4.7 & 9.1 & - & - & 0.4 & - & 14.3 \\
Kazakhstan & 15.0 & 13.7 & 36.4 & - & 2.5 & 0.1 & 67.6 \\
Turkmenistan & 6.9 & 21.8 & - & - & - & - & 28.7 \\
Uzbekistan & 2.7 & 37.1 & 3.5 & - & 1.7 & - & 45.0 \\
\hline
\end{tabular}

Source: BP Statistical Review of World Energy 2019, s. 9.

In Table 1, among the primary energy consumption amounts of 2017, Kazakhstan comes first with 67.6 million TEO, followed by Uzbekistan, Turkmenistan and Azerbaijan respectively. While the share of coal in the primary energy consumption is high in Kazakhstan, the share of natural gas is higher in Uzbekistan and Turkmenistan.

When the consumption in 2018 is analyzed in Table 2, it is seen that the total consumption of Azerbaijan remains the same; there is an increase in Kazakhstan and Turkmenistan, but a decrease in Uzbekistan. 
Çemrek/Eskişehir Technical Univ. J. of Sci. and Tech. A-Appl. Sci. and Eng. 21 (1)-2020

In the ranking of countries within the total primary energy consumption in 2018, even though the values in 2017 changed partially, the ranking was preserved exactly.

Table 2. Primary Energy Consumption of Turkic Republics in 2018 (Million TEO)

\begin{tabular}{lccccccc}
\hline & Oil & Natural Gas & Coal & Nuclear & Hydraulic & Renewable & Total \\
\hline Azerbaijan & 4.6 & 9.3 & - & - & 0.4 & - & 14.4 \\
Kazakhstan & 16.4 & 16.7 & 40.8 & - & 2.3 & 0.1 & 76.4 \\
Turkmenistan & 7.1 & 24.4 & - & - & - & - & 31.5 \\
Uzbekistan & 2.6 & 36.6 & 3.1 & - & 1.6 & - & 43.9 \\
\hline
\end{tabular}

Source: BP Statistical Review of World Energy 2019, s. 9.

\section{MATERIAL AND METHOD}

\subsection{Purpose of the Study and Data}

In this study, the relationship between energy: electricity consumption per capita (kwh) and GDP: Per Capita Gross Domestic Product (\$) series was examined through panel data analysis for the years between 1991 and 2014 with the annual data for Azerbaijan, Kazakhstan, Kyrgyzstan, Tajikistan, Turkmenistan and Uzbekistan. The data were obtained from the World Development Indicators (WDI) of World Bank.

\subsection{Panel Data Analysis}

In econometric studies, three types of data are used: time series data [18], cross section data, and mixed data (a combination of time series and cross section data). If the same section unit is monitored over time, such mixed data is called panel data. As a result of the measurement of certain sample units such as individuals, firms, households, cities, countries over time, the panel data structure that expresses the data set for the same item in different time frames is reached [19-22].

A simple linear panel data regression model is generally expressed as follows:

$$
\mathrm{Y}_{\text {it }}=\beta_{1 \mathrm{it}}+\beta_{2 \mathrm{it}} \mathrm{X}_{2 \mathrm{it}}+\ldots+\beta_{\mathrm{kit}} \mathrm{X}_{\mathrm{kit}}+\varepsilon_{\mathrm{it}}
$$

$\mathrm{i}=1 \ldots \mathrm{N}$ and $\mathrm{t}=1 \ldots \mathrm{N}$

There are three methods to be used in the prediction stage with pooled regression as the prediction method while adapting both the time and cross-section data to the model. These methods are: Classical Model, Fixed Effects Model and Random Effects Models.

The classic model includes models where both constant and slope coefficients are constant according to units and time. This model is formulized as follows;

$$
\mathrm{Y}_{\mathrm{it}}=\beta_{\mathrm{o}}+\sum_{\mathrm{k}=1}^{\mathrm{k}} \beta_{\mathrm{k}} \mathrm{X}_{\mathrm{kit}}+\mathrm{e}_{\mathrm{it}}
$$

and the parameters can be estimated by the Least Squares method.

General representation of fixed effects model is as follows;

$$
\mathrm{Y}_{\mathrm{it}}=\beta_{1 \mathrm{it}}+\beta_{2 \mathrm{it}} \mathrm{X}_{2 \mathrm{it}}+\ldots+\beta_{\mathrm{kit}} \mathrm{X}_{\mathrm{kit}}+\varepsilon_{\mathrm{it}}
$$

Random effects model is presented as;

$$
\mathrm{Y}_{\mathrm{it}}=\beta_{1 \mathrm{it}}+\beta_{2 \mathrm{it}} \mathrm{X}_{2 \mathrm{it}}+\ldots+\beta_{\mathrm{kit}} \mathrm{X}_{\mathrm{kit}}+\varepsilon_{\mathrm{it}}+\mu_{i}
$$

(Güriş 2018:3) 


\subsection{Results of Analysis and Findings}

\subsubsection{Descriptive statistics}

Descriptive statistics for the series are given in Table 3.

Table 3. Descriptive Statistics for Series

\begin{tabular}{ccc}
\hline & Energy & GDP \\
\hline Average & 1977.222 & 2578.327 \\
Std. Dev. & 1423.742 & 2476.700 \\
Skewness & 0.554329 & 1.424304 \\
Kurtosis & 2.124360 & 4.301610 \\
Jarque-Bera & 11.97521 & 58.85253 \\
Prob. & 0.002510 & 0.000000 \\
$\mathbf{N}$ & 144 & 144 \\
\hline
\end{tabular}

\subsubsection{Panel unit root tests}

After the descriptive statistics, unit root tests to investigate the stationarity of the series are given in Table4.

Table 4. Unit Root Tests

\begin{tabular}{cccc}
\hline Series & Model & Test & p \\
\hline \multirow{2}{*}{ Energy } & Level & Levin, Lin \& Chu t & 0,2835 \\
& Level & ADF - Fisher & 0,7010 \\
& Level & PP - Fisher Chi-square & 0,9977 \\
Energy & 1 Difference Taken & Levin, Lin \& Chu t & 0.0000 \\
& 1 Difference Taken & ADF - Fisher & 0.0000 \\
1 Difference Taken & Level & PP - Fisher Chi-square & 0.0000 \\
GDP & Level & Levin, Lin \& Chu t & 0,9999 \\
& Level & ADF - Fisher & 0,9999 \\
& 1 Difference Taken & PP - Fisher Chi-square & 0,9775 \\
GDP & 1 Difference Taken & Levin, Lin \& Chu t & $<0.001$ \\
& 1 Difference Taken & ADF - Fisher & $<0.001$ \\
\hline
\end{tabular}

Examining Table 4, it is seen that the hypothesis claiming the existence of unit root in the series for energy consumption and GDP series cannot be rejected with 95\% reliability for all three tests. Therefore, it can be said that both series are not stationary at the level. However, it is seen that both series become stagnant after taking 1 degree difference. In the following analysis, the series that have been stabilized by taking 1 difference will be studied.

As a result of the unit root test, it can be seen from Table 8 that the level values are not stationary even if the series contains the trend, which is one of the deterministic components. This means that the shock effects on the series do not disappear in time. The variables become stabilized when the first difference is taken for all statistics test values, that is, I (1) carries the process. Since the same degree of stability is detected, cointegration analysis can be started.

\subsubsection{Panel Cointegration Tests}

After unit root tests, panel cointegration analyzes are required to determine the long-term relationships between the series. Panel Cointegration test results for the related series are given in Table 5. 
Table 5. Pedroni Cointegration Results (For GDP and Energy series, when GDP variable is considered as dependent variable

\begin{tabular}{|c|c|c|c|c|}
\hline \multicolumn{5}{|c|}{ Pedroni Cointegration Test } \\
\hline & Statistic & $\mathbf{p}$ & Weighted Statistic & $\mathbf{p}$ \\
\hline Panel v & -0.969724 & 0.8339 & -0.787511 & 0.7845 \\
\hline Panel rho & -1.069697 & 0.1424 & -1.731105 & 0.0417 \\
\hline Panel PP & -2.805185 & 0.0025 & -3.825145 & 0.0001 \\
\hline \multirow[t]{2}{*}{ Panel ADF } & -0.404096 & 0.3431 & -0.406280 & 0.3423 \\
\hline & Statistic & $\mathbf{p}$ & & \\
\hline Group rho & -0.606903 & 0.2720 & & \\
\hline Group PP & -3.500231 & 0.0002 & & \\
\hline Group ADF & 0.359224 & 0.6403 & & \\
\hline
\end{tabular}

According to Table 5, it is seen that the hypothesis claiming that there is no cointegration between GDP and energy consumption cannot be rejected for 5 of all test statistics. Hence, cointegration was found between the energy consumption and GDP series according to Pedroni cointegration method.

Table 6. Kao Cointegration Results

\begin{tabular}{lcc}
\hline & t-Statistic & p \\
\hline \multicolumn{1}{c}{ KAO Co-integration Test } & $-2,7571$ & 0,0029 \\
\hline Error Variance & 0,00408 & \\
HAC Variance & 0,00243 & \\
\hline
\end{tabular}

According to the Kao cointegration test, there is a cointegration relationship between the series. Revealing the cointegration structure, the panel model estimation results made by accepting GDP dependent variable are given in Table 7.

Table 7. Panel Model Estimation Results

\begin{tabular}{|c|c|c|c|c|c|c|c|}
\hline Model & $\begin{array}{c}\text { Model } \\
\text { Significance }\end{array}$ & $\mathbf{R}^{2}$ & $\begin{array}{c}\text { Independent } \\
\text { variable }\end{array}$ & Coefficient & Std. Error & $\mathbf{t}$ & Prob. \\
\hline \multirow{2}{*}{ Pooled Panel } & \multirow{2}{*}{0,000} & \multirow{2}{*}{0,2588} & Energy & 0.484811 & 0.069622 & 6.963525 & 0.0000 \\
\hline & & & $\mathrm{C}$ & 0.026907 & 0.007469 & 3.602648 & 0.0004 \\
\hline \multirow{2}{*}{$\begin{array}{l}\text { Sectional Fixed } \\
\text { Effects }\end{array}$} & \multirow{2}{*}{0.0000} & \multirow{2}{*}{0,2436} & Energy & 0.480029 & 0.071516 & 6.712228 & 0.0000 \\
\hline & & & $\mathrm{C}$ & 0.026806 & 0.007550 & 3.550708 & 0.0005 \\
\hline \multirow{2}{*}{$\begin{array}{l}\text { Fixed Time } \\
\text { Dependent } \\
\text { Effects }\end{array}$} & \multirow{2}{*}{0,000} & \multirow{2}{*}{0,6529} & Energy & 0.108732 & 0.063951 & 1.700249 & 0.0918 \\
\hline & & & $\mathrm{C}$ & 0.018962 & 0.005190 & 3.653745 & 0.0004 \\
\hline \multirow{2}{*}{$\begin{array}{l}\text { Fixed Effects } \\
\text { Depending on } \\
\text { Time and Section }\end{array}$} & \multirow{2}{*}{0.000} & \multirow{2}{*}{0,6654} & Energy & 0.076089 & 0.064730 & 1.175483 & 0.2424 \\
\hline & & & $\mathrm{C}$ & 0.018273 & 0.005106 & 3.578837 & 0.0005 \\
\hline \multirow{2}{*}{$\begin{array}{l}\text { Cross Sectional } \\
\text { Random Effects }\end{array}$} & \multirow{2}{*}{0,000} & \multirow{2}{*}{0,2588} & Energy & 0.484811 & 0.070328 & 6.893544 & 0.0000 \\
\hline & & & $\mathrm{C}$ & 0.026907 & 0.007545 & 3.566443 & 0.0005 \\
\hline \multirow{2}{*}{$\begin{array}{l}\text { Time-dependent } \\
\text { Random Effects }\end{array}$} & \multirow{2}{*}{0,000} & \multirow{2}{*}{0,0817} & Energy & 0.232498 & 0.059083 & 3.935077 & 0.0001 \\
\hline & & & $\mathrm{C}$ & 0.021673 & 0.010875 & 1.992855 & 0.0483 \\
\hline
\end{tabular}

C: Fixed Term Model Significance: $\mathrm{H}_{0}$ : Regression model is meaningless.

In Table 7, the model results obtained for various panel data regression methods are shown collectively. Analyzing the results, it is seen that the panel data regression method gives the highest $\mathrm{R}^{2}$ for constant 
and time-dependent cross-section effects for panel models made by considering GDP per capita dependent variable and energy consumption as independent variable. In addition, the direction of the effect was positive in all models. However, Hausmann Test results to test which panel regression model valid are is given in Table 8 .

Table 8. Hausmann Test Results

\begin{tabular}{ccc}
\hline Variable & Section Effect & Time Effect \\
\hline Energy & 0,7125 & 0,0000 \\
\hline
\end{tabular}

As a result of Hausmann test to check " $\mathrm{H}_{0}$ : Random effects model is valid" hypothesis, it is seen that the time dependent random effects model is valid for GDP-Energy Consumption models. When the random effects models are examined, it is seen that the energy consumption series has a positive effect on the GDP.

\section{CONCLUSION}

The amount of energy consumption is among the main indicators used in measuring the development levels of countries. There is a positive relationship between energy consumption and economic growth. Relationships between energy consumption and economic growth have a major impact on countries' energy policies.

As a result of the econometric analysis, cointegration between the energy consumption and GDP series was found according to the Pedroni cointegration method for the 6 Central Asian Countries examined. In addition, it is seen that there is a cointegration relationship between the series examined according to the Kao cointegration test.

According to the panel model estimation results made by accepting GDP dependent variable after the cointegration structure is revealed, it is seen that panel effects regression method gives the highest R2 for time and cross-sectional fixed effects for panel models made by considering GDP per capita as dependent variable and energy consumption as independent variable. In addition, the direction of the effect was positive in all models. As a result of Hausmann test, it is seen that time dependent random effects model is valid for GDP-Energy Consumption models. When the random effects models are examined, it is seen that the energy consumption series has a positive effect on the GDP.

According to these results, there is a unidirectional causality relationship from energy to economic growth. The growth hypothesis is valid for the Central Asian countries handled in this study. According to the growth hypothesis, electricity consumption directly contributes to economic growth as an important complement to labor and capital during the production process. Policies to be implemented to reduce electricity consumption will negatively affect economic growth. Accordingly, technologies and management programs to increase energy efficiency and savings should be supported in these countries. By encouraging the development of competition in the electricity industry, it will be possible to reduce the production costs of electricity and to ensure the sustainability of economic growth by transferring the resources created to the exporting sectors.

\section{REFERENCES}

[1] Apergis N., Payne J. (2009). Energy Consumption and Economic Growth: Evidence from the Commonwealth of Independent States. Energy Economics 2009; 31:5: 641-647.

[2] Kraft J. Kraft A. On the Relationship Between Energy and GNP. Journal of Energy and Development 1978; 3: 401-403. 
[3] Masih A.M. Masih R. Energy Consumption, Real Income and Temporal Causality: Results from a Multicountry Study Based on Cointegration and Error Correction Modeling Techniques. Energy Economics 1996; 18:165-183.

[4] Lee C.C. Chun-Ping C. Energy Consumption and Economic Growth in Asian Economies: A More Comprehensive Analysis Using Panel Data. Resource and Energy Economics 2008; 30:1: 50-65.

[5] Hou Q. The Relationship Between Energy Consuption Growths and Economic Growth in China. International Journal of Eonomics and Finance 2009; 1(2): 232-237.

[6] Belke A. H, Dreger C., Frauke D. Energy Consuption and Economic Growth New Insights Into the Cointegration Relationship. Ruhr Economic Papers 2010; 190: 1-22.

[7] Adhikari D. Yanying C. (2012). Energy Consumption and Economic Growth: A Panel Cointegration Analysis for Developing Countries. Review of Economics and Finance 2012; 3(2): 68-80.

[8] Mutascu M. A bootstrap Panel Granger Causality Analysis of Energy Consumption and Economic Growth in the G7 Countries. Renewable and Sustainable Energy Reviews 2016; 63:166-171.

[9] Usta C. Berber M. Türkiye'de Enerji Tüketimi Ekonomik Büyüme İlişkisinin Sektörel Analizi.Ekonomik ve Sosyal Araştırmalar Dergisi 2017; 13(13): 173-187.

[10] Ilgaz Yıldırım, B., Şahin D. Geçiş Ekonomilerinde Turizme ve Enerjiye Dayalı Büyüme Hipotezinin Analizi: Panel Nedensellik Analizi. Iğdır Üniversitesi Sosyal Bilimler Dergisi 2018; 16: 437-457.

[11] Syzdykova A. Orta Asya Ülkelerinde Enerji Tüketimi ve Ekonomik Büyüme İlişkisi: Panel Veri Analizi. AKÜ İktisadi ve İdari Bilimler Fakültesi Dergisi 2018; 20(1): 87-99.

[12] Esen Ö. Bayrak M. Kamu Harcamaları ve Ekonomik Büyüme İlişkisi: Geçiş Sürecindeki Türk Cumhuriyetleri Üzerine Bir Uygulama. Bilig Türk Dünyas1 Sosyal Bilimler Dergisi 2015; 73: 231248.

[13] Yıldırır Keser H., Çetin I .Kara ile Çevrili Olmanın İhracat Üzerine Etkisi: Gelişmekte Olan Avrupa ve Orta Asya Ülkeleri Üzerine Bir Analiz. Ankara Üniversitesi SBF Dergisi 2016; 71(1): 199-230.

[14] Kök R., Ekinci R. Ay Yalçınkaya E. Ülke Riski Bileşenlerinin Reel Sektör Üzerindeki Etkisi: Azerbaycan-Kazakistan-Rusya ve Türkiye Örneği. Bilig Türk Dünyası Sosyal Bilimler Dergisi 2017; 83: 281-302.

[15] Çelik T., Çelik B., Barak D. Geçiş Ekonomilerinde Reel Döviz Kuru ve Ekonomik Büyüme İlişkisi. Süleyman Demirel Üniversitesi İktisadi ve İdari Bilimler Fakültesi Dergisi 2017; 22(3):877-890.

[16] Rjoub H. Aga M., Oppong C., Sunju N., Fofack A.D. The Impact of FDI Inflows on Economic Growth: Evidence from Landlocked Countries in Sub-Saharan Africa". Sosyal Bilimler Dergisi 2017; 10(1): 153-168.

[17] BP Statistical Review of World Energy 2019. 
[18] Pekmezci A. and Dilek M. The Comparison of Performances of Widely Used Cointegration Tests, Communications in Statistics - Simulation and Computation, 2016; 45:6, 2070-2080

[19] Baltagi B. Econometric Analysis of Panel Data. 2nd ed. UK: Wiley 2001.

[20] Greene, W. H. Econometric Analysis. India, USA: Pearson Education, 2003.

[21] Yerdelen Tatoğlu F. Panel Zaman Serileri Analizi Stata Uygulamalı. İstanbul: Beta Yayıncılık, 2018.

[22] Güris, Selahattin (Editör), Uygulamalı Panel Veri Ekonometrisi. İstanbul:.Der Yayınları, 2018. 